\title{
Influence of Financing on Quality of University Education in Kenya
}

\author{
Dr. Calleb Gudo, PhD \\ Lecturer, Jaramogi Oginga University of Science and Technology \\ callebgudo@yahoo.com
}

\begin{abstract}
Higher education in Kenya is characterized by students' preference for public universities due to government financial support associated with such an admission. This demand for university education has significantly increased and continues to swell against a backdrop of decreasing ratio of financial allocation to universities from the Government. Since 2000/1 academic year, only about 6\% of registered Kenya Certificate of Secondary Education candidates, which is an equivalent of $25 \%$ of candidates who meet minimum university entry requirements, gets admitted on Government sponsorship to public universities. It is this surplus supply of qualified students that created market for privatization of university education in public and private universities in Kenya. It is argued in this paper that the current arrangement in financing higher education in Kenya is inadequate and aggravated by ineffective university management. Lack of enough funding has lead to shortage of basic learning resources and teaching staff, students' agitation and administrative weaknesses. The effect of the inadequate financing on delivery of services at the universities is questionable quality of graduates. It is recommended that the Government should enhance managerial capacity of top university managers besides developing strategies for meeting financial gaps required by the universities for production of quality graduates.
\end{abstract}

Keywords: Higher education, Quality, demand and privatization.

\section{BACKGROUND}

It is feared that universities within the African continent have suffered decline in provision of quality education. Several factors are believed to have contributed to the decline in quality of university education in Africa. These include a decline in per unit costs amid rapidly rising enrollments; insufficient numbers of qualified academic staff in higher education institutions as the result of brain drain, retirements and HIV/AIDS; low internal and external efficiency; and poor governance (Materu, 2007).

According to Ajayi (2006), the demand for higher education in Nigeria, particularly at the university level, has outgrown what the government could cope with. This led to the advent of private higher education and concern for quality assurance at this level. Tumwesigye (2006) found out that expansion of university education in Uganda was faster, primarily due to the increasing social demand for higher education in the country.

This trend was particularly evident in Ethiopia, where only three public universities existed until 1996. By 2005, about 60 private for-profit higher education institutions had been founded in Ethiopia. This has led to mixed feelings among the Ethiopian public. While some laud the opportunities and advantages these new institutions bring, others are apprehensive that the quality of education might be compromised by an expansion motivated by monetary gain (Alemu, 2010).

Kenya similarly placed considerable importance on the role of education in promoting economic and social development after the achievement of independence in 1963. This resulted in rapid expansion of higher education system despite dwindling national economic fortunes.

The Kenya economy and by extension the education sector faced major challenges in the 1970s and 1980s. Some of these were due to poor terms of international trade, including the oil crisis, as well as increasing misunderstanding, corruption and ethnically-inspired inefficiencies and inequity. It is in this context that the IMF pushed for the implementation of Structural Adjustment Programmes (SAPs) in the 1980s when Kenya sought financial assistance to implement some of its development policies. SAPs recommended that the Government reduce its budgetary support to the education sector. 


\section{Dr. Calleb Gudo}

Consequently in 1994, the Government of Kenya decreased the education budget from $37 \%$ of its total annual recurrent budget to about 30\%. Further, in 2006/07 public expenditure on higher education decreased by $9.4 \%$ (Sihanya, 2008).

Prior to SAP policies, universities received their revenues from the Government purse. A cost sharing policy was implemented from 1991 where students would pay for their tuition and maintenance fees. The fees paid were to be sources of income for the universities to enable them to meet the costs of providing quality education. The result was a rapid rise in student enrolment not only in public universities, but also in private universities as shown in Table 1.1.

Table1. Student Enrolment in Kenyan Universities, 2002/03 - 2010/11

\begin{tabular}{|c|c|c|c|c|c|c|c|c|c|c|}
\hline \multicolumn{2}{|c|}{ Type of University } & $\mathbf{2 0 0 2 / 0 3}$ & $\mathbf{2 0 0 3 / 0 4}$ & $\mathbf{2 0 0 4 / 0 5}$ & $\mathbf{2 0 0 5 / 0 6}$ & $\mathbf{2 0 0 6} / \mathbf{0 7}$ & $\mathbf{2 0 0 7 / 0 8}$ & $\mathbf{2 0 0 8 / 0 9}$ & $\mathbf{2 0 0 9 / 1 0}$ & $\mathbf{2 0 1 0 / 2 0 1 1}$ \\
\hline \multirow{4}{*}{ Public } & Enrolment & 71,832 & 72,550 & 81,491 & 81,677 & 91,337 & 97,107 & 100,648 & 122,700 & 150,926 \\
\cline { 2 - 11 } & $\begin{array}{c}\text { Yearly } \\
\text { increase } \\
\text { as a \% }\end{array}$ & & 1.0 & 12.32 & 0.23 & 11.83 & 6.32 & 3.65 & 21.91 & 23.0 \\
\hline \multirow{3}{*}{ Private } & Enrolment & 8,680 & 9,541 & 12,660 & 13,606 & 20,892 & 21,132 & 22,198 & 20,089 & 31,327 \\
\cline { 2 - 11 } & $\begin{array}{c}\text { Yearly } \\
\text { increase } \\
\text { as a \% }\end{array}$ & & 9.92 & 32.69 & 7.47 & 53.55 & 1.15 & 5.05 & -9.5 & 55.95 \\
\hline
\end{tabular}

Sources: Statistical Abstract (Republic of Kenya, 2009, 2011).

The student enrolment shown in Table 1 relates to data from seven public universities and eleven accredited private universities in Kenya. The table illustrates fluctuating rate of increase in student enrolment in both public and private universities. The fluctuations were higher among private universities.

It was anticipated that revenues from self sponsored students in public universities would be used to expand facilities and enhance quality. However, studies reveal the reverse as true. A study conducted among public universities in Kenya in 2006 found out that the provision of physical facilities such as lecture theatres, library resources and computer services were inadequate (Olel, 2006). Other studies have shown that research and publications by faculty have sharply dropped due to heavy teaching responsibilities - brought about by the rising student numbers, plus the emerging trend where lecturers moonlight so as to make some extra money to supplement their pay (Chacha 2004; Olel 2006). Without adequate research, what informs the curriculum taught in universities?

While university expansion has led to increased access, the quality of the education provided by the existing and newly established higher education institutions has continued to raise serious concern (Mayunga, Stefan \& Christoph, 2009). Similar views have been expressed by other scholars (Kiamba 2004; Sihanya (2009)), who have argued that the student enrolment explosion, has adversely affected the quality of education in public universities. It is thought the programme was implemented without specific staff recruitment or training and without expansion or upgrades to the physical learning resources at the universities. In a study by Oanda, Chege, \& Wasonga (2008), it was found out that the drive for privatization of higher education and the growth of private university institutions were not developed out of a policy context initiated by Kenya.

Currently public universities receive most of their funding from the government. Of this amount, about eighty percent $(80 \%)$ of government capitation to public universities goes to pay emoluments leaving only twenty percent $(20 \%)$ for operations and maintenance. Private universities on the other hand, fund themselves through tuition fees and they are run as 'not-for-profit' trusts. They do not receive any direct benefits from the government. They can, however, apply for tax waivers on some imported equipment (Republic of Kenya, 2009).

University education and training is expensive and requires considerable investment. In 2009/10, the proportion of public spending by the Kenya government at university level as percentage of total education allocation was estimated at $11 \%$. This excluded direct household financing paid by students.

Table 2 shows that the recurrent expenditure on university education in Kenya was expected to decline by $7.8 \%$ in the fiscal year 2011/2012 while the development expenditure for university during the same period was expected to more than double. It is difficult to explain the decline in recurrent expenditure, but the increase in development expenditure could be attributed to the expected double intake by the universities later in the year. 
Influence of Financing on Quality of University Education in Kenya

Table2. Expenditure for University Education in Kenya 2007/08 - 2011/12 (Kshs. million)

\begin{tabular}{|c|c|c|c|c|c|c|}
\hline Description & $\mathbf{2 0 0 7 / 2 0 0 8}$ & $\mathbf{2 0 0 8 / 2 0 0 9}$ & $\mathbf{2 0 0 9 / 2 0 1 0}$ & $\mathbf{2 0 1 0 / 2 0 1 1}$ & $\mathbf{2 0 1 1 / 2 0 1 2}$ & $\begin{array}{c}\text { \% Drop or } \\
\text { increase }\end{array}$ \\
\hline $\begin{array}{c}\text { Recurrent } \\
\text { expenditure }\end{array}$ & $10,941.5$ & $12,899.8$ & $16,266.5$ & $33,784.5$ & $31,137.4$ & 7.8 \\
\hline $\begin{array}{c}\text { Development } \\
\text { Expenditure }\end{array}$ & 693.0 & $1,967.0$ & $2,340.4$ & $3,022.2$ & $7,404.7$ & 145.0 \\
\hline
\end{tabular}

Source: Economic Survey (Republic of Kenya, 2012).

\section{Statement of The Problem}

The expanding enrolments in public universities in Kenya were considered a revenue stream and business opportunity to individual and corporate investors in private higher education. This has led to establishment of several private universities. In the midst of this singular focus on revenues by private and public universities, basic internal quality assurance processes were ignored. The question that was asked is: What is the influence of financing on quality of university education in Kenya? The study therefore sought to determine the influence of financing and other variables on provision of quality university education.

\section{Methodology}

This study adopted a survey design. Data was collected from two public universities and two private universities in Kenya in the year 2010. The sample size was 652 respondents comprising 502 undergraduate degree students, 127 lecturing staff and 23 library staff. Questionnaires were prepared to solicit specific information from each category of respondents. Statistical Packages for Social Sciences (SPSS) was used as a tool to generate frequencies and percentages. Some information was obtained from websites and publications of government agencies. Care was taken to ensure that secondary information used in this document were authentic and provided by the relevant bodies.

\section{RESEARCH OBJECTIVES}

- To determine the influence of financing on quality of physical learning facilities in Kenyan public and private universities

- To find out influence of financing on effectiveness of faculty members in performing their duties in Kenyan public and private universities.

\section{LIMITATION OF THE STUDY}

The information in the study was collected from four universities only; two being public while the other two were private universities. Whereas it could have been plausible to visit all the universities, the four universities were sampled in a way that the findings were representative and allowed generalization of findings to both public and private universities in Kenya.

\section{RESUlts AND Discussions}

\subsection{Physical Learning Facilities}

One objective of the study was to determine the influence of financing on quality of physical learning facilities in Kenyan public and private universities. The facilities referred to in this study include lecture rooms, laboratory equipment, number and quality of computers, library resources and availability of sporting facilities. The researcher asked respondents for their opinion on whether the facilities were satisfactory or not. Responses were as shown in Table 4.25.

Table3. Satisfaction Level of Physical Facilities among Staff and Students in Private and Public Universities in Kenya

\begin{tabular}{|l|l|l|}
\hline \multirow{2}{*}{ Physical facilities } & Universities \\
\cline { 2 - 3 } & Private (satisfaction level as a \%) & Public (satisfaction level as a \%) \\
\hline Lecture Rooms & 68.889 & 41.463 \\
\hline Laboratory Equipment & 80.0 & 35.366 \\
\hline Number and Quality of Computers & 84.444 & 31.706 \\
\hline Sporting Facilities & 63.158 & 44.411 \\
\hline
\end{tabular}




\section{Dr. Calleb Gudo}

Results in table 3 above indicate that lecturers in private universities were satisfied with the facilities available teaching and learning facilities but their counterparts in public universities were not satisfied with the quantity and quality of the facilities. Shortage of lecture rooms in public universities implied that some students missed sitting space during lectures or attended lectures as they sat outside the lecture rooms thus, causing lack of concentration among learners. Shortage of facilities such as laboratory equipment and quality computers for practical lessons denied students opportunities to develop their skills and encouraged rote learning. Thus, effective teaching and learning in public universities was hampered by lack of enough essential facilities.

Shortage of physical facilities in public universities in Kenya is well documented. World Bank (2000), Cheboi (2006), Republic of Kenya (2006) and Kiganda (2009) noted that financial resources directed to university education were inadequate and that accelerated growth in student numbers in the public universities had not been matched by expansion of physical facilities and academic infrastructure. According to Okwakol (2008) most African universities do not have adequate physical facilities such as lecture rooms, office, and library and laboratory spaces to provide a suitable learning and teaching environment. She noted that $55 \%$ of laboratory equipment in most departments in universities were not in a state in which they could be used to carry out experiments. The net effect of this scenario was that only about half the experiments were done.

\subsection{Library Resources}

The study targeted 24 library staff in all universities, but only 23 responded resulting in a response rate of $95.8 \%$ which was considered adequate for this study. The distribution of respondents is shown in the table below.

Table4. Library Staff

\begin{tabular}{|c|c|c|c|c|}
\hline University & Frequency & Percent & Valid Percent & Cumulative Percent \\
\hline Baraton & 2 & 8.7 & 8.7 & 8.7 \\
\hline MMUST & 4 & 17.4 & 17.4 & 26.1 \\
\hline UON & 11 & 47.8 & 47.8 & 73.9 \\
\hline USIU & 6 & 26.1 & 26.1 & 100.0 \\
\hline Total & 23 & 100.0 & 100.0 & \\
\hline
\end{tabular}

Table 4 shows that $47.8 \%$ of the respondents were drawn from the University of Nairobi. This high number was attributed to high number of colleges that the University has. Each of these colleges has a library.

Analysis was done on perceived satisfaction level among library staff with selected aspects of library services in private and public universities. The selected areas for investigation were library space, print journals, internet facilities, current books and e-journals. Results are shown in the table 5.

Table5. Satisfaction Level of Library Resources among Staff and Students in Private and Public Universities in Kenya

\begin{tabular}{|c|c|c|}
\hline \multirow{2}{*}{ Library resources } & \multicolumn{2}{|c|}{ Universities } \\
\cline { 2 - 3 } & Private (satisfaction level as a \%) & Public (satisfaction level as a \%) \\
\hline Library Space & 100 & 66.667 \\
\hline Print Journals & 100 & 66.667 \\
\hline Internet Facilities & 100 & 40.0 \\
\hline Current books and e-journals & 100 & 60.0 \\
\hline
\end{tabular}

The results in Table 5 above shows that library staff in private universities were satisfied with the available space, print journals, internet services and current books and e-journals. Library staff in the public universities, on the other hand were dissatisfied with the various services. This is not new as shortage of physical facilities had been cited by academicians in other studies (Olel, 2006; Ndethiu, 2007; Okwakol, 2008; Eshiwani, 2009). From the results, it is evident that shortage of library resources was a major hindrance to effective teaching and learning in public universities.

\subsection{Sporting Facilities}

Students were asked to state their level of satisfaction with the sporting facilities provided by the university. Results are shown below. 
Table6. Sporting Facilities

\begin{tabular}{|c|c|c|c|c|c|}
\hline \multicolumn{3}{|c|}{ Public Universities } & \multicolumn{3}{c|}{ Private Universities } \\
\hline Response & F & \% & Response & F & \% \\
\hline VD & 86 & 25.294 & VD & 7 & 4.605 \\
\hline D & 103 & 30.294 & D & 49 & 32.237 \\
\hline S & 123 & 36.176 & S & 64 & 42.105 \\
\hline HS & 28 & 8.235 & HS & 32 & 21.053 \\
\hline Total & $\mathbf{3 4 0}$ & $\mathbf{9 9 . 9 9 9}$ & Total & $\mathbf{1 5 2}$ & $\mathbf{1 0 0 . 0 0}$ \\
\hline
\end{tabular}

$V D=$ Very Dissatisfactory, $D=$ Dissatisfactory, $S=$ Satisfactory, $H S=$ Highly Satisfactory, $F=$ Frequency $\%=$ Percentage

Table 6 above shows that $63.158 \%$ and $44.411 \%$ of students from private and public universities respectively were satisfied with provision of sporting facilities. This was interpreted to mean that public universities did not provide adequate sporting facilities. The inference was that inadequate provision of sporting activities in public universities in Kenya negatively influenced the quality of teaching and learning in these institutions (Keim, 2008; Fox, Barr-Anderson, Neumark-Sztainer \& Wall, 2010; Taylor \& Turek, 2010).

\subsection{Faculty Performance of Research and Teaching Duties}

The second objective of the study was to find out influence of financing on effectiveness of faculty members in performing their duties in Kenyan public and private universities. The first part of this analysis was about teaching duties while second part was about research duties.

\subsection{Ratio of Lecturers to Students}

For effective teaching to take place at a university, there is a minimum ratio of lecturing staff against number of enrolled students to be achieved which was recommended by Commission for Higher Education (CHE). The recommended lecturer/student ratio was compared against what was available at the selected universities. Table 7 shows the recommended lecturer/staff ratios.

Table7. Recommended ratio per department of staff to students

\begin{tabular}{|c|c|}
\hline Programme & Lecturer/Student Ratio \\
\hline Applied Sciences & $1: 10$ \\
Arts and Humanities & $1: 15$ \\
Medical and Allied Sciences & $1: 7$ \\
Pure and Natural Sciences & $1: 10$ \\
Social Sciences & $1: 18$ \\
\hline
\end{tabular}

Source: $C H E$ (2010)

Attempt was made to analyse the lecturer/students ratio per department of each of the selected universities. Information was obtained from the relevant offices and the results that there was shortage of staff in all the departments of University of Nairobi. It also showed that the number of lecturers available was $44.54 \%$ of the expected number of lecturers. Assume that the short fall was filled by part time lecturers as is the international practice, then part time lecturers formed $55.46 \%$ of the teaching staff. From the table it is evident that Education and External Studies and Humanities and Social Sciences experienced larger shortage of lecturers.

At Masinde Muliro University there was experiencing shortage of lecturers. It also showed that the University had $53.182 \%$ of its teaching staff requirement. This meant that $47 \%$ of its teaching staff were part time lecturers.

Full time lecturers at USIU were $25.501 \%$ of the expected number of lecturing staff. The table also shows that management at USIU had made deliberate effort to recruit more part time staff which currently forms $74.499 \%$ of its teaching force to fill the short fall in teaching requirement. This shows serious shortage of full time lecturers.

Baraton was experiencing a shortage of lecturers. The shortage of 21 lecturers represented $23.333 \%$ in the three faculties. This shortage was very serious since this was a short fall after considering both full time and part time lecturing staff. It shows that the university was experiencing difficulties in attracting personnel for the teaching positions. It was not understandable that amidst this difficulty the University had more lecturers than necessary in Science and Technology faculty. The suspicion was that the extra staff were serving religious purposes in addition to their teaching duties. 


\section{Dr. Calleb Gudo}

The results above show that the shortage was more serious in private universities than public universities. It was therefore interpreted that shortage of lecturers reduced efficiency of lecturers in offering effective services for quality education in private and public universities in Kenya. This finding corroborates earlier studies, Waituru (1999), Maria et al (2003) and Mutisya (2010) which singled out shortage of lecturers as serious threat to offering quality university education. As was found out, private and public universities have more part time than permanent lecturers. Part time staff are available for the scheduled lecturing hours but not for consultations with students. This arrangement denied students opportunity for deeper understanding of subject matter through critical enquiry in guided debate and practice.

\subsection{Research Duties}

The researcher wanted to find out the views of lecturing staff regarding the quality of research at the selected universities. The respondents were asked to respond to a statement, "Quality of research done by staff is high". Responses are shown in the table below.

Table8. Quality of Research

\begin{tabular}{|c|c|c|c|c|c|}
\hline \multicolumn{3}{|c|}{ Public Universities } & \multicolumn{3}{c|}{ Private Universities } \\
\hline Response & F & \% & Response & F & \% \\
\hline SD & 5 & 6.096 & SD & 8 & 17.778 \\
\hline D & 26 & 31.707 & D & 13 & 28.889 \\
\hline A & 41 & 50.00 & A & 20 & 44.444 \\
\hline SA & 10 & 12.195 & SA & 4 & 8.889 \\
\hline Total & $\mathbf{8 2}$ & $\mathbf{9 9 . 9 9 8}$ & Total & $\mathbf{4 5}$ & $\mathbf{1 0 0 . 0 0}$ \\
\hline
\end{tabular}

$S D=$ Strongly Disagree, $D=$ Disagree, $A=$ Agree, $S A=$ Strongly Agree, $F=$ Frequency, $\%=$ Percentage

Table 8 shows that $62.195 \%$ and $53.333 \%$ of the respondents from private and public universities respectively were in agreement that quality of research was high.

Attempt was made to find out if increase in student numbers has had effect on research activities. The question responded to was, "Quantity and quality of research has been negatively affected by number of students admitted in to this university". Results are shown in the table below.

Table9. Effect of Student Numbers on Quality and Quantity of Research

\begin{tabular}{|c|c|c|c|c|c|}
\hline \multicolumn{3}{|c|}{ Public Universities } & \multicolumn{3}{c|}{ Private Universities } \\
\hline Response & NO & \% & Response & NO & \% \\
\hline SD & 9 & 10.976 & SD & 7 & 15.556 \\
\hline D & 26 & 31.707 & D & 20 & 44.444 \\
\hline A & 20 & 24.390 & A & 10 & 22.222 \\
\hline SA & 27 & 32.927 & SA & 8 & 17.778 \\
\hline Total & $\mathbf{8 2}$ & $\mathbf{1 0 0 . 0 0}$ & Total & $\mathbf{4 5}$ & $\mathbf{1 0 0 . 0 0}$ \\
\hline
\end{tabular}

$S D=$ Strongly Disagree, $D=$ Disagree, $A=$ Agree, $S A=$ Strongly Agree

Table 9 above shows that the number of admitted students in public universities has had negative effect on quality and quantity of research. The staff who disagreed with the statement were $42.683 \%$ and $60.0 \%$ from public and private universities respectively. It was interpreted that increased student numbers negatively affected quality and quantity of research in private and public universities in Kenya. It was established that the negative effect was higher in public universities than private universities. It was inferred that private universities had experienced long term problem of conducting quality research due to increased student numbers alongside shortage of lecturers and reliance on part time staff for teaching. The findings compare to Olukoju (2002), Chacha (2004), Olel (2006) and Eshiwani (2009) who found that there was decline in terms of output, quality and regularity of publications among faculty staff.

The researcher wanted to find out if a research policy exists in the universities and whether the policy is known to the lecturers. The statement was, "A well articulated research policy exists and is known to all stakeholders". Responses were shown in the table below. 
Table10. Research Policy

\begin{tabular}{|c|c|c|c|c|c|}
\hline \multicolumn{3}{|c|}{ Public Universities } & \multicolumn{3}{c|}{ Private Universities } \\
\hline Response & F & \% & Response & F & \% \\
\hline SD & 13 & 15.854 & SD & 5 & 11.111 \\
\hline D & 26 & 31.707 & D & 11 & 24.444 \\
\hline A & 33 & 40.244 & A & 25 & 55.556 \\
\hline SA & 10 & 12.195 & SA & 4 & 8.889 \\
\hline Total & $\mathbf{8 2}$ & $\mathbf{1 0 0 . 0 0}$ & Total & $\mathbf{4 5}$ & $\mathbf{1 0 0 . 0 0}$ \\
\hline
\end{tabular}

$S D=$ Strongly Disagree, $D=$ Disagree, $A=$ Agree, $S A=$ Strongly Agree, $F=$ Frequency, $\%=$ Percentage

Table 10 above shows that $52.439 \%$ and $64.445 \%$ of lecturers from public and private universities respectively agreed that a well articulated research policy exists and is known to the lecturers. Even a larger proportion of staff in private than public universities were aware of the detail in research policies of their universities, there was need to communicate the research policies among staff in private universities and more effort in public universities.

Attempt was made to find out how credible and transparent was the criteria for disbursement of research funds. Respondents were asked to respond to this statement; "Credible and transparent criteria exist for disbursement of research funds and are known to all stakeholders". Responses are shown in the table below.

Table11. Criteria for Disbursement of Research Funds

\begin{tabular}{|c|c|c|c|c|c|}
\hline \multicolumn{3}{|c|}{ Public Universities } & \multicolumn{3}{c|}{ Private Universities } \\
\hline Response & F & \% & Response & F & \% \\
\hline SD & 12 & 14.634 & SD & 5 & 11.111 \\
\hline D & 31 & 37.805 & D & 13 & 28.889 \\
\hline A & 30 & 36.585 & A & 19 & 42.222 \\
\hline SA & 9 & 10.976 & SA & 8 & 17.778 \\
\hline Total & $\mathbf{8 2}$ & $\mathbf{1 0 0 . 0 0}$ & Total & $\mathbf{4 5}$ & $\mathbf{1 0 0 . 0 0}$ \\
\hline
\end{tabular}

$S D=$ Strongly Disagree, $D=$ Disagree, $A=$ Agree, $S A=$ Strongly Agree, $F=$ Frequency, $\%=$ Percentage

Table 11 shows that lecturers in private universities who agreed with the statement were $60.0 \%$. Staff in public universities who agreed with the statement were $47.561 \%$. The interpretation was that credibility and transparency of the criteria for disbursement of research funds in private universities in Kenya was satisfactory, but unsatisfactory for public universities. The management of public universities should ensure that criteria for disbursement of research funds does not become an impediment to effective conduct of research in private and public universities.

It is important to note that the effect of inadequate finance was compounded by ineffective institutional management processes in Kenyan public and private universities. It was found out that teaching and learning in public universities was negatively affected by low staff morale, lack of sufficient engagement of staff and students in decision making, inadequate communication between management and stakeholders, admissions of students beyond the capacity of physical facilities available in the institutions. Negative tribalism (ethnicity) and nepotism was found to hinder equal employment opportunities in private and public universities, particularly, the search for senior management. Private universities did not have teamwork among staff and did not satisfactorily engage students and staff in decision making (Gudo, 2012). According to K'Okul (2010), students' riots were attributed mainly to misunderstanding between the students and the university authority and poor management followed by inadequate learning facilities and ineffective guidance and counseling services. In a study by Maina (2009), it was found that colleges that keep students informed of the challenges that they faced in providing services and how they were handled gave students an opportunity to experience management in action and were better prepared for challenges. In March 2014, university staff in all public universities went on strike claiming fraudulent use of cash by university management. The staff unions accused top management of public universities of misusing funds that were provided by the government for their house allowance and salary increase (Damary, 2014). It was unfortunate that this strike was due to mischievous behavior of top university management of public universities. Industrial actions by students and staff in universities disrupt learning and negatively impact on the quality of education. All parties involved should at all times aim at providing solutions. 


\section{CONCLUSIONS}

It was concluded that quality of services by faculty members was lowered by shortage of lecturing staff in both private and public universities. Quality of service provision by lecturers in public universities was further lowered by large number of admitted students and unsatisfactory criteria for disbursement of research funds. There was a significant difference between public and private universities in availability of teaching and learning facilities and the quality of physical facilities in private universities was, in many cases, better than those in public universities. Thus, the quality of education offered in public universities was hampered by lack of enough essential facilities, inadequate number of teaching staff and ineffective management processes. These same factors affected the quality of education offered in private universities, but at a lower level compared to public universities.

\section{RECOMMENDATIONS}

- There was need for the government to increase funding to public universities and ensure innovative engagement with the private sector to raise finance needed by the universities. Such a move would allow universities to employ more lecturers to match the number of enrolled students in accordance with CHE recommendation of student staff ratios. Other measures to include effectively communicating criteria for obtaining and disbursement of research funds.

- To overcome shortage of physical facilities in public universities, student admissions should be based on available facilities. Secondly, the management should plan and budget for gradual improvement of available facilities and purchase new state of the art facilities to enhance quality learning.

- The top university management should undergo routine in-service management and leadership courses to enable them build capacity to effectively handle students and staff in a fast changing global community.

\section{REFERENCES}

Ajayi, T (2006). Private Higher education in Kenya. New Trends in Education: Growth and Expansion of Private Higher Education in Africa. Paris. International Institute for Educational Planning $95-108$.

Alemu, D.S (2010). Expansion vs Quality: Emerging Issues of For-Profit Private Higher Education Institutions in Ethiopia. International Review of Education Vol 56 pp 51-61.

Benjamin SJ, Marathamuthu MS, Muthaiyah S and Raman M (2011). Affordability of private tertiary education: a Malaysian study. International Journal of Social Economics. 38(4): 382-406.

Bowers-Brown $\mathrm{T}$ (2006). Widening participation in higher education amongst students from disadvantaged socio-economic groups. Tertiary Education and Management. 12(1): 59-74.

Chacha, N.C (2004). Reforming Higher Education in Kenya: Challenges, Lessons and Opportunities. A paper presented at the State University of New York workshop with the Parliamentary Committee on Education, Science and Technology, Naivasha, Kenya.

Cheboi, B (2006, $6^{\text {th }}$ November). Funding Patterns and their Effects on Quality of Higher Education in Kenya. Presented at Kenyatta University. Conference paper. Nairobi.

Chou YK (2003). The Australian growth experience, 1960-2000: human capital, R\&D or steady-state growth? Australian Economic Review. 36: 397-414.

Commission for Higher Education (2010). Press Release, by E.M Standa -CEO CHE. Daily Nation Wednesday November 17, 2010, p.22.

Commonwealth of Australia (2005). Financing Higher Education in Australia.

Damary, R (2014). University Unions may Strike over 7.8billion dispute. The Star. Thursday, March 6,2014 p 6.

Eshiwani, G (2009). University Expansion in Eastern Africa: Challenges and Options in Higher Education. Inter-University Council for East Africa (IUCEA). Newsletter Vol. 39 pp 17-22.

Fox, C.K; Barr-Anderson, D; Neumark-Sztainer, D \& Wall, M (2010). Physical Activity and Sports Team Participation: Associations with Academic Outcomes in Middle School and High School Students. Journal of School Health. Vol 80 Issue 1. Pp31-37. 
Gudo C O, et al (2011). University Expansion in Kenya and Issues of Quality Education: Challenges and Opportunities. International Journal of Business and Social Science. 2 (20): 203 - 214.

Higher Education Loans Board (HELB) (2002). Higher Education Loans Board (HELB) Review.

Higher Education Loans Board (HELB) (2012). Sunday Nation July 8, 2012 p19.

Keim, M (2008). Building Peace through Sport in Western Cape, South Africa. Africa Peace and Conflict Journal. Vol 1 No 1 pp 95-109.

Kenyatta U (2013). The Harmonised Jubilee Coalition Manifesto. Agenda for Kenya 2013-2017 and Beyond. (www.scribd.com/doc extracted on November 18, 2013)

Kiamba, C (2004). Privately Sponsored Students and Other Income-Generating Activities at the University of Nairobi. JHEA/RESA Vol. 2, No. 2, 2004, pp.53-73

Kiganda, C (2009). East African Universities Vice Chancellors Urged to shift Students Roles to Centre and make the Partners and Responsible Stakeholders. Inter-University Council for East Africa (IUCEA). Newsletter Vol. 39 pp 8-16.

K'Okul, F (2010). Perception of Students on the Status of Guidance and Counseling in Selected Universities in Kenya for Minimizing Student Riots. Unpublished PhD Thesis. Kenyatta University.

Materu, P (2007). Higher Education Quality Assurance in Sub-Saharan Africa: Status, Challenges, Opportunities and Promising Practices. Washington D.C. World Bank.

Maina, R.K (2009). Encouraging Youth Entrepreneurship: The Role of Institutional Environments and Learning Experiences. International Journal of Knowledge, Culture and Change Management. Vol 9, No 10, pp107-118.

Mayunga H.H.N, Stefan, B \& Christoph, H (2009). Developing Internal Quality Assurance Mechanisms - Towards an East African quality assurance framework. In the European Union Association. Trends in Quality assurance: A Selection of papers from the $3^{\text {rd }}$ European Quality Assurance Forum. Brussels pp 39 - 44.

Mutisya, K (2010, December 22). How the wrong policies turned public universities into cacophonous markets. Daily Nation, p.13.

Ndethiu, S.N (2007). The Role of Kenyatta University in Promoting Good Reading Habits among Undergraduate Students. Unpublished PhD Thesis. Kenyatta University.

Oanda, I.O; Chege, F \& Wasonga, D (2008). Privatization and Private Higher Education in Kenya: Implications for access, Equity and Knowledge Production. CODESRIA. Dakar: Imprimerie Saint Paul.

Okwakol, M.J.N (2008). Challenges and Prospects for Quality Assurance in Science and Technology Education in African Countries. The Uganda Higher Education Review. Journal of the National Council for Higher Education, Vol 5 No.2 Pp 17-26.

Olel, M. A. (2006). The Effect of Privately Sponsored Students Programme on Efficiency and Equity in Public Universities in Kenya and Uganda. Unpublished PhD Thesis. Maseno University.

Olukoju, A. (2002). The Crisis of Research and Academic Publishing in Nigerian Universities: The Twentieth Century and Beyond. A Paper for the $28^{\text {th }}$ Annual Spring Symposium, "African Universities in the $21^{\text {st }}$ Century", Dakar. CODESRIA.

Republic of Kenya (1988). Education and Manpower Training for the Next Decade and Beyond: Report of the Presidential Working Part.(Kamunge Report). Nairobi: Government Printer.

Republic of Kenya (1999). Totally Integrated Quality Education and Training: Report of the Commission of Inquiry into the Education System of Kenya (Koech Report). Nairobi: Government Printer.

Republic of Kenya (2003). Report of the Sector Review and Development; Ministry of Education Science and Technology. Nairobi: Government Printer.

Republic of Kenya (2004). Statistical Abstract 2003. Nairobi: Government Printer.

Republic of Kenya (2005). A Policy Framework for Education, Training and Research: Meeting the Challenges of Education, Training and Research in Kenya in the $21^{\text {st }}$ Century, Sessional paper No. 1 of 2005, Nairobi: Government Printer. 
Republic of Kenya (2006). Transformation of Higher Education and Training in Kenya to Secure Kenya's Development in Knowledge Economy: Report of The Universities Inspection Board (Kinyanjui Report), Nairobi: Government Printer.

Republic of Kenya (2007). Kenya Vision 2030: A Globally Competitive and Prosperous Kenya. Nairobi: Government Printer.

Republic of Kenya (2009). Statistical Abstract 2009. Kenya National Bureau of Statistics. Nairobi: Government Printer.

Republic of Kenya (2009). Financing University Education in Kenya: A Report to the Ministry of Higher Education Science and Technology. Nairobi. Government Printer.

Republic of Kenya (2010). Constitution of Kenya. Nairobi: Government Printer.

Republic of Kenya (2011). Statistical Abstract. Nairobi. Government Printer.

Republic of Kenya (2012). Economic Survey. Nairobi. Government Printer.

Sihanya, B (2008). How IMF Policies Constrict Policy Space in Kenya's Education Sector. The Impact of IMF Policies on Education, Health and Women's Rights in Kenya: Resource Book. Nairobi: Action Aid Kenya.

Taylor, M.J \& Turek, G.M (2010). If Only She Would Play? The Impact of Sports Participation On Self Esteem, School Adjustment and Substance Abuse Among Rural and Urban African American Girls. Journal of Sports Behaviour Vol 33. No 3 pp315-336.

The Dearing Report-National Committee of Inquiry into Higher Education. (1997). Online: http://www.hero.ac.uk/uk/inside_he/government_and_higher_education/major_education_report s4024.cfm.

Tumwesigye, G (2006). Private Higher education in Uganda. New Trends in Education: Growth and Expansion of Private Higher Education in Africa. Paris: International Institute for Educational Planning $202-229$.

Waituru, M (1999). Accelerated student Enrolments in Kenyan Public Universities: Implications for Quality Instruction. Unpublished Master of Education Thesis. Kenyatta University.

World Bank (2000). Higher Education in Developing Countries: Peril and Promise. Washington D.C: World Bank.

\section{AUTHOR'S BIOGRAPHY}

Dr. Calleb Gudo, is an Education Consultant, Expert in Comparative Education and a Lecturer at Jaramogi Oginga Odinga University of Science and Technology in the School of Education. 